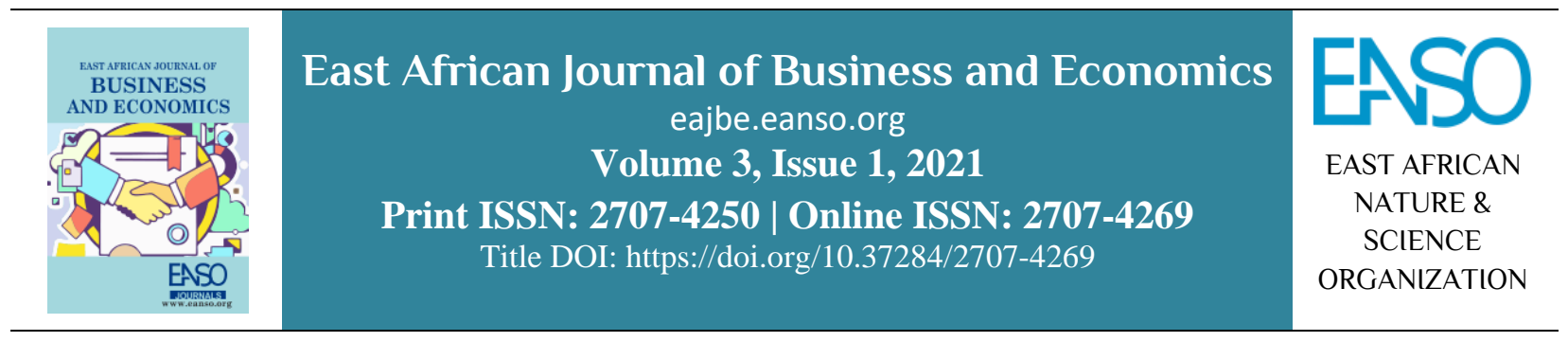

Original Article

\title{
Ethical Principles and Procurement Management in Selected Public Secondary Schools in Kericho County, Kenya.
}

\author{
Joyce Cheruto Rotich ${ }^{1 *}$, Dr. Pauline Keitany, PhD ${ }^{1}$, Dr. Hellen W. Sang, PhD \\ ${ }^{1}$ University of Kabianga, P. O. Box 2030 - 20200, Kabianga, Kenya. \\ *Correspondence email: polynkeitany@gmail.com.
}

Article DOI: https://doi.org/10.37284/eajbe.3.1.298

\section{Date Published: ABSTRACT}

16 March 2021 Ethical practices are norms that are accepted and should be adopted in institutions to ensure a flawless procurement management process. The

Keywords: procurement system varies depending on the organisation in a major way due

Ethical Principles, Procurement Management, Correlation Design. to the fact that most projects are donor-funded, thus creating inconsistency in public schools. This study aimed to determine the relationship between ethical principles and procurement management in selected public secondary schools in Kericho County. The study was guided by the following theories deontological theory and virtue ethical theory. The study adopted a correlation research design. The target population used 220 public secondary schools, which comprised of 1100 tendering committees. The study used stratified and simple random sampling techniques to sample the school. The sample size was 294 respondents, which were derived using Yamane's formula. Questionnaires were used for data collection. It is hoped that the findings of the study may benefit school management, scholars, policymakers, and other stakeholders. Descriptive and inferential methods were utilised for data analysis and presentation. ANOVA results indicated that ethical principles had a significant relationship with procurement management $(p<0.05)$. Ethical principles should be adhered to since it has improved procurement management significantly. Therefore, there is a need to tighten internal control systems in detecting procurement corruption and fraud to ensure integrity in the process.

\section{APA CITATION}

Rotich, J. C., Keitany, P., \& Sang, H. W. (2021). Ethical Principles and Procurement Management in Selected Public Secondary Schools in Kericho County, Kenya. East African Journal of Business and Economics, 3(1), 57-64. https://doi.org/10.37284/eajbe.3.1.298 


\section{CHICAGO CITATION}

Rotich, Joyce, Cheruto, Pauline. Keitany, and Hellen W. Sang. 2021. "Ethical Principles and Procurement Management in Selected Public Secondary Schools in Kericho County, Kenya.”. East African Journal of Business and Economics 3 (1), $57-64$. https://doi.org/10.37284/eajbe.3.1.298

\section{HARVARD CITATION}

Rotich, J. C., Keitany, P., and Sang, H. W. (2021) "Ethical Principles and Procurement Management in Selected Public Secondary Schools in Kericho County, Kenya”, East African Journal of Business and Economics, 3 (1), pp. 57-64. doi: 10.37284/eajbe.3.1.298.

\section{IEEE CITATION}

J. C. Rotich, Keitany, P, and Sang, H. W., "Ethical Principles and Procurement Management in Selected Public Secondary Schools in Kericho County, Kenya”, EAJBE, vol. 3, no. 1, pp. 57-64, Mar. 2021.

\section{MLA CITATION}

Rotich, Joyce, Cheruto, Pauline. Keitany, and Hellen W. Sang. "Ethical Principles and Procurement Management in Selected Public Secondary Schools in Kericho County, Kenya". East African Journal of Business and Economics, Vol. 3, no. 1, Mar. 2021, pp. 57-64, doi:10.37284/eajbe.3.1.298

\section{INTRODUCTION}

Ethics plays a very important role in the business environment which may cause an impact on the public and also on the brand of the company. Ethics in procurement should be adhered to so as to avoid related ethical consequences. In relation to this, a monopoly should not be practised in the procurement process. The risk increases in the public sector where a single supplier is used (Kinoti, 2013). For organisations to achieve value for money and contribute to efficient service delivery, public procurement practice must adopt a strong ethical stand. It must be practised so as to be void of leakages and loss, corruption, and vendor favouritism. The way to address these concerns is by adopting a strong sense of ethics such as avoiding collusion, discouraging fake competition, removing any arbitrariness from the bid evaluation process, ensuring that the goods and services received reflect the precise quantities actually delivered and using slicing to avoid adopting the appropriate procurement method (Leenders et al., 2014).

According to previous empirical studies, it is noted that implementation of ethical practices in procurement leads to higher organisational performance hence the need to minimise unethical practices in the procurement process (Thomson \& Jackson, 2007). Odhiambo and Kamau (2003) stated that procurement has both economic and political impact; thus, it is vital to make sure the process is economical and ethical. Meaning it should be understood by all players such as procuring entities, government, academic entities, stakeholders, general public and suppliers.

Some public sector organisations such as schools are not free from unethical behaviour during the procurement process. Unethical behaviour is an act committed by the government at the highest level to change the central functions of the state, allowing leaders to get public goods in a biased manner (Lindskog et al., 2010). The applicable ethics in public procurement in government entities must be adhered to so as to maintain codes of conduct, ethical concepts and principles and avoid ethical risks and actions from unethical practices as underlined in the Public Procurement and Asset Disposal Act of 2015. Occasionally procurement is mannered by mechanisms that are related to unfair procedures, tender awards and lack of transparency. Several entities are faced with challenges at the prequalification level, during quality assurance, warehouse supplies, customs clearance, underinvoicing during imports, among other issues (Chigudu, 2014). Therefore, this study was carried out to establish the relationship between ethical practices and procurement management.

In Kenya, the $30 \%$ action in procurement reservations and preference for women, youth and persons with disabilities was a directive by his Excellency the President. Procurement officers are required to diligently pursue it in a maximum manner. It was meant to enhance businesses owned by these groups. It was also aimed at uplifting the economy, create employment and revolutionise the 
domestic economy (GOK, 2015). A number of studies have been carried out relating to ethical practices in the procurement process and the finding indicates that many organisations observe guidelines put in place by the Public Procurement and Asset Disposal Act, 2015 and the manual for secondary schools 2005 . However, it is not yet clear if the procurement process in the public sector in Kenya is free from unethical practices. Therefore, this study was carried out to ascertain ethical practices and procurement management in public secondary schools in Kericho County, Kenya. Therefore, the paper determines the relationship between ethical principles and procurement management in selected public secondary schools in Kericho County.

\section{LITERATURE REVIEW}

\section{Theoretical Review}

Deontological ethics theory was first proposed in the $18^{\text {th }}$ century by Immanuel Kant. The theory prioritises duties over consequences. This comes as voluntary and informed obedience of moral law irrespective of the situation (Hunja, 2003). The theory has at least three key features that include: first, duty shall be done for duty's sake which means that the right or wrongness of an act is a matter of intrinsic moral features of that kind of activities such as lying. Second, humans shall be treated as objects of intrinsic value and thirdly; a moral principle is imperative categorically to everyone.

Ndolo and Njagi (2014) indicate that institutions that practice this theory have a code of ethics and this leads to reduced improper behaviours. The theoretical approach to ethics shows that morality emanates from reason and it is a moral duty to act according to the moral laws. Thus, all organisations should adopt ethical practices so as to get rid of ethical dilemmas. This implies that compliance with good governance and ethics enhanced responsibility (Belak \& Rozman, 2012).

Duran and McNutt (2010) argue that the code of ethics can be effectively implemented and established if this Kantian ethical principle is followed and incorporated as part of the organisation's strategy. McNutt also reveals that if the adoption of a code of ethics requires duties to be assigned and identified, failure to fulfil leads to frustration of the implemented ethical principles. This theory is potential to the study as it would explain how public secondary schools can formulate ethical policies and codes of conduct and ensure they flow effectively, particularly in areas such as conflict of interests and gifts.

\section{Empirical Literature}

Ethical concepts and principles refer to the acceptable norms that institutions should adopt to maintain a flawless procurement process. It is discussed in five dimensions which include transparency, confidentiality, due diligence, integrity and, impartiality and fairness. The main objective of procurement transparency is the principle of openness which is the cornerstone of the procurement process.

Oloo et al. (2017) conducted a study on the effects of procurement practices on the performance of public hospitals in Kenya. The study was comparative in nature. The target population in this study was level four hospitals in Kisii and Homabay Counties. The findings indicated that the public hospitals review procurement policies frequently. Results further indicated that respondents agree procurement integrity is high. The study made a recommendation to improve supplier selection and performance. The current study sought to establish the relationship between ethical practices and procurement management in selected public secondary schools in Kericho County, Kenya.

Nyangoto (2018) conducted a study on ethics and procurement performance in humanitarian organisations in Kisii. The researcher found that employees were not trained adequately hence posing a lot of challenges in procurement ethics. Also, findings indicate that ethics should not be overlooked in the acceptance of gifts and violation of bid-rigging policies should be eradicated as these lead to bias towards specific suppliers. This study focused on procurement performance, while the current study focused on procurement management.

Maintaining transparency ensures procedure control and effective technique for preventing unethical behaviour. Ntayi et al. (2013) indicated that procuring entities should make their procurement proceedings transparent through publicly 
advertising and making their results public too. Hansson and Holmgren agree that procurement laws are formulated to increase efficiency in public procurement processes.

Kenya Public Procurement Regulatory Authority (PPRA) has taken advantage of advanced technology to enhance transparency and the results of RFQs (Request for quotation) on the notice boards. According to Raymond (2008), transparency in public procurement and assuring investors that contracts were given in an equitable and fairway. Rotchanakitumnuai (2013) argues that governance in procurement entails integrity, accountability, transparency and fairness. Nijaki \& Worrel (2012) gives insight that policymakers in procurement should embrace transparency in their procedures. The public procurement players should be fair to provide an opportunity for suppliers to compete for tenders. This was further supported by World Bank (2011) which revealed that good procurement is impartial, reliable and consistent. This implies that it offers a level playing field to all the interested contractors, suppliers and consultants, who in turn enhance their purchaser's options and chances.

Kitheka (2018) indicates that the buyer should ensure the principle of fairness, transparency and equality when handling suppliers. Pagell et al. (2010) also indicated that buyers should treat their suppliers fairly as partners as opposed to exploiting them. Poppo and Zheng (2014) revealed that perceptions of fairness influence the transaction costs and without taking such considerations, the contracts favoured only the party with more bargaining power.

Gesuka and Namusonge (2013) did a study in Kenya about factors affecting compliance with public procurement regulations. The study revealed that confidentiality is a major issue in public procurement and lack of it leads to non-compliance with public procurement regulations. It is one of the legal requirements in Kenya for the procuring entities to maintain the confidentiality of all the information regarding the procurement process, the content of tenders, quotations or proposals. A study by Magoro (2010) focusing on public procurement policy in South Africa revealed that the primary objectives of procurement that include equity, fairness, cost-effectiveness and transparency are undermined by secondary objectives such as the disadvantaged people, women and youth.

\section{RESEARCH METHODOLOGY}

This study adopted a correlation research design to examine the relationship between ethical practices and procurement management. In this study, the target population comprised of 220 registered public secondary schools in Kericho County. The target population comprised 1100 tendering committee in the selected public secondary schools in Kericho County. A stratified sampling technique was used in the study to extract information from the tendering committee in public secondary school per subcounty. Stratification ensured that the data was a representation of Kericho County. The proportion method was used to obtain the sample size per each strata representing the sub-county. Due to these reasons, the researcher calculated the sample size of participants in the study using the Yamane (1967) formula. A sample of 294 respondents was selected. Both structured and non-structured questionnaires were utilised in data collection. Content and construct validity was ensured through review by supervisors to ensure content is well measured. Cronbach's alpha coefficient was used to measure the internal consistency of the research instruments.

Piloting was conducted to ascertain the reliability of the instrument at the selected public schools in Bomet County. The study adopted a descriptive statistics analysis. The data collected was coded for easy data entry, cleaning and editing using the Statistical Package for Social Sciences (SPSS). The questionnaires that are fully filled were only considered and checked for accuracy before analysis. Descriptive statistical analysis was done using means and standard deviation. Multiple linear regression models were considered in the study and inferential statistics as a tool that indicated the relationship between variables. ANOVA and correlation analysis were also used to test the significance of variables at $5 \%(p=0.05)$. The presentation was done using pie charts, bar graphs, and frequency tables. However, the following diagnostic test was conducted before using multiple regression. These tests were done for the following assumption normality, linearity, autocorrelation, multi-collinearity and homoscedasticity test. 


\section{DATA ANALYSIS, DISCUSSION AND INTERPRETATIONS}

\section{Descriptive Statistics}

Descriptive statistics were analysed from the Likert Scale of 1-5 to produce mean and standard deviation based on the frequencies. Where $1=$ strongly disagree, 2 = disagree, $3=$ neutral, $4=$ agree and 5 $=$ strongly agreed. The results were used to interpret data collected on ethical practice and procurement management. The descriptive results were discussed as per the objective of the study. Ethical principles descriptive statistics were computed from the Likert scale to obtain mean and standard deviation. The results of frequencies were used to obtain the mean, standard deviation, minimum and maximum as indicated in Table 1.

Table 1: Ethical Principles Results

\begin{tabular}{|c|c|c|c|c|c|c|c|c|c|}
\hline & SA (5) & A (4) & $\mathbf{N}(3)$ & D (2) & SD (1) & Min & Max & Mean & SD \\
\hline $\begin{array}{l}\text { Award of tender goes to the } \\
\text { lowest responsive and } \\
\text { responsible bidder }\end{array}$ & $\begin{array}{l}103 \\
(39.5 \%)\end{array}$ & $\begin{array}{l}115 \\
(44.1 \%)\end{array}$ & $\begin{array}{l}43 \\
(16.5 \%)\end{array}$ & $\begin{array}{l}0 \\
(0.0 \%)\end{array}$ & $\begin{array}{l}0 \\
(0.0 \%)\end{array}$ & 3.00 & 5.00 & 4.2299 & .71308 \\
\hline $\begin{array}{l}\text { Transparency is paramount } \\
\text { to all the procurement } \\
\text { processes }\end{array}$ & $\begin{array}{l}113 \\
(43.3 \%)\end{array}$ & $\begin{array}{l}94 \\
(36.0 \%)\end{array}$ & $\begin{array}{l}43 \\
(16.5 \%)\end{array}$ & $\begin{array}{l}11 \\
(4.2 \%)\end{array}$ & $\begin{array}{l}0 \\
(0.0 \%)\end{array}$ & 2.00 & 5.00 & 4.1839 & .85748 \\
\hline $\begin{array}{l}\text { Supplier's information has } \\
\text { not often disclosed without } \\
\text { their prior consent }\end{array}$ & $\begin{array}{l}39 \\
(14.9 \%)\end{array}$ & $\begin{array}{l}127 \\
(48.7 \%)\end{array}$ & $\begin{array}{l}88 \\
(33.7 \%)\end{array}$ & $\begin{array}{l}7 \\
(2.7 \%)\end{array}$ & $\begin{array}{l}0 \\
(0.0 \%)\end{array}$ & 2.00 & 5.00 & 3.7586 & .73326 \\
\hline $\begin{array}{l}\text { Tenders are advertised on } \\
\text { public domain }\end{array}$ & $\begin{array}{l}144 \\
(55.2 \%)\end{array}$ & $\begin{array}{l}117 \\
(44.8 \%)\end{array}$ & $\begin{array}{l}0 \\
(0.0 \%)\end{array}$ & $\begin{array}{l}0 \\
(0.0 \%)\end{array}$ & $\begin{array}{l}0 \\
(0.0 \%)\end{array}$ & 4.00 & 5.00 & 4.5517 & .49827 \\
\hline $\begin{array}{l}\text { Fair and equal treatment is } \\
\text { accorded to all providers } \\
\text { and integrity in the school's } \\
\text { procurement management } \\
\text { with no preference } \\
\text { whatsoever }\end{array}$ & $\begin{array}{l}143 \\
(54.8 \%)\end{array}$ & $\begin{array}{l}104 \\
(39.8 \%)\end{array}$ & $\begin{array}{l}14 \\
(5.4 \%)\end{array}$ & $\begin{array}{l}0 \\
(0.0 \%)\end{array}$ & $\begin{array}{l}0 \\
(0.0 \%)\end{array}$ & 3.00 & 5.00 & 4.4943 & .59885 \\
\hline
\end{tabular}

Table 1 indicated that the school sufficiently gave tenders to bidders to the lowest responsive and responsible $(M=4.2299)$. However, the variation in giving the lowest responsive and responsible bidders was low $(S D=0.59885)$. Transparency was adequately paramount to all procurement processes $(M=4.1839)$. Variance in procurement process transparency was low $(S D=0.85748)$. Supplier's information was moderately kept confidential since the disclosure was made prior to their consent $(M=$ 3.7586; $S D=0.73326$ ). The results further illustrated that tenders were sufficiently advertised in the public domain $(M=4.5517 ; S D=0.49827)$. Furthermore, the suppliers were given fair and equal treatment, which was greatly associated with integrity in the school's procurement management $(M=4.4943 ; S D=0.59885)$. Therefore, there was no preference whatsoever with the school's procurement management.
Oloo et al. (2017) concurred that there is a need for absolute integrity in the procurement process despite the study done in level four hospital in Kisii and Homabay counties. However, the result differs from Nyangoto (2018), where the study found that there was a lot of challenges in procurement ethics that lead to massive violation of bid-rigging in humanitarian organisations in Kisii County. This finding concurs with Raymond (2011) and Rotchanakitumnuai (2013), who found that transparency, integrity, accountability and fairness play an important role in good governance in procurement. Hence, transparency, fairness and equality are important in the procurement process to ensure high procurement management.

\section{Inferential Statistics}

ANOVA analysis was used to test ethical principles were investigated on procurement management. 
The hypotheses were tested using a 5\% significance level.

Table 2: ANOVA for Relationship Between Ethical Principles and Procurement Management

\begin{tabular}{|c|c|c|c|c|c|c|c|}
\hline & & & $\begin{array}{l}\text { Sum of } \\
\text { Squares }\end{array}$ & df & $\begin{array}{l}\text { Mean } \\
\text { Square }\end{array}$ & $\mathbf{F}$ & Sig. \\
\hline Procurement & Between & (Combined) & 37.309 & 9 & 4.145 & 50.571 & .000 \\
\hline Management $*$ Ethical & Groups & & & & & & \\
\hline Principles & Within Groups & & 20.575 & 251 & .082 & & \\
\hline & Total & & 57.884 & 260 & & & \\
\hline
\end{tabular}

Source: Research Data (2021)

ANOVA results revealed that there existed a significant relationship between ethical principles and procurement management $\left(F_{(3,257)}=50.571, p\right.$ $<0.05$ ). Similarly, Oloo et al. (2017) found that there existed a significant relationship between ethical practices on procurement practice. This implies that ethical principles affected procurement management.

Ethical principles had a significant relationship with procurement management in selected public secondary schools in Kericho County $(\beta=0.656, p$ $<0.05)$. The study rejected the null hypothesis. This implied that ethical principles had a significant positive effect on procurement management. Procurement management had 0.656 variations as a result of ethical principles. ANOVA result also concurred that there existed a significant relationship between ethical principles and procurement management. Kitheka (2018) found that ethical principles like fairness, transparency and equality had a significant influence on procurement management. Therefore, organisations should improve on ethical principles so as to improve procurement management.

\section{CONCLUSIONS AND RECOMMENDATIONS}

Findings on ethical principles indicated that the school sufficiently gave tenders to bidders with the lowest responsive and responsible. Transparency through all procurement processes was sufficient. However, the supplier's information was moderately kept confidential based on the fact that disclosure was made prior to their consent. Suppliers were also given fair and equal treatment due to integrity with procurement management. Ethical principles were therefore found to have a significant influence on procurement management.

The study concluded that ethical principles had a significant influence on procurement management. Transparency was one of the ethical principles that ensured sufficient procurement processes. However, confidentiality was one of the moderate practice ethical principles which were important in ensuring disclosure of supplier's information prior to consent. Ethical principles also ensured that there are fairness and equality in treating suppliers to ensure integrity.

The study recommended that ethical principles should be adhered to since it has improved procurement management significantly. There is a need for school management should ensure suppliers' information should be kept confidential and only release according to the supplier's consent unless it's a matter of national security. Equality and fairness should ensure equality and equality should be ensured.

\section{REFERENCES}

Belak, J., \& Rozman, M. P. (2012). Business ethics from Aristotle, Kant and Mill's perspective. Kybernetes, 4(10), 1607-1624.

Chigudu, D. (2014). Public procurement in Zimbabwe: issues and challenges. Journal of Governance and Regulation, 3(4), 21-26.

Duran, X., \& McNutt, P. (2010). Kantian ethics within transaction cost economics. International journal of social economics, 37(10), 755-763. 
Gesuka, D. M., \& Namusonge, G. S. (2013). Factors affecting compliance of public procurement regulations in Kenya: A case study of Butere district. International Journal of Social Sciences and Entrepreneurship, 1(5), 882-896.

Government of Kenya (GoK). (2015). Kenya's Transformative Programme: Accessing Business Opportunities for Women, Youth and Persons with Disabilities. Retrieved from http://esango.un.org/SideEvents/documents/765

Hansson, L., \& Holmgren, J. (2011). Bypassing public procurement regulation: A study of rationality in local decision-making. Regulation \& Governance, 5(3), 368-385.

Hunja, R. R. (2003). Obstacles to public procurement reform in developing countries. Public Procurement: The Continuing Revolution, Kluwer Law International, 13-22.

Kinoti, J. B., Arasa, R., Waititu, G. A., \& Guyo, W. (2013). Influence of the procurement regulatory framework on the implementation of Supply Chain Management ethics in Government Ministries in Kenya. Machakos University

Kitheka, S. S. (2018). Influence of Sourcing Ethics on Procurement Performance of State Corporations in Kenya. Doctoral dissertation, JKUAT.

Leenders, M., Johnson F., Flynn, A., \& Fearon, H. (2014). Purchasing and Supply Management (15th ed.). New Delhi: Tata McGraw-Hill.

Lindskog, H., Brege, S., \& Brehmer, P. O. (2010). Corruption in public procurement and private sector purchasing. Journal of Organizational Transformation \& Social Change, 7(2), 167188.

Magoro, M. J. (2010). The implementation of the procurement policy with reference to the Reconstruction and Development Housing programme in Limpopo province. Master's dissertation, University of Pretoria.

Ndolo, J. \& Njagi, E. (2014). Role of Ethics in Procurement Process Effectiveness in the Water Sector in Kenya: (A Case Study of EWASCO,
Embu County). International Journal of Supply Chain Management, 3(3), 128-133.

Nijaki, L. K., \& Worrel, G. (2012). Procurement for sustainable local economic development. International Journal of Public Sector Management, 25(2), 133-153.

Ntayi, J. M., Ngoboka, P., \& Kakooza, C. S. (2013). Moral schemas and corruption in Ugandan public procurement. Journal of Business Ethics, 112(3), 417-436.

Nyangoto, O. D. S. (2018). Factors Affecting Ethics on Procurement Performance in Humanitarian Organisations: Case Study of Kenya Red Cross - Kisii County. Kisii University.

Odhiambo, W., \& Kamau, P. (2003). Public procurement: lessons from Kenya, Tanzania and Uganda.Working Paper No. 208. OECD Development Centre.

Oloo, O., Atambo, W., \& Muturi, W. (2017). Effects of Procurement Practices on the Performance of Public Hospitals in Kenya: A comparative study of Hospitals in Homabay and Kisii Counties. International Journal of Social Science and Information Technology, 3(2), 1899-1916.

Pagell, M., Wu, Z., \& Wasserman, M. E. (2010). Thinking differently about purchasing portfolios: an assessment of sustainable sourcing. Journal of supply chain management, 46(1), 57-73.

Poppo, L., \& Zhou, K. Z. (2014). Managing contracts for fairness in buyer-supplier exchanges. Strategic Management Journal, 35(10), 1508-1527.

Public Procurement and Asset Disposal Act, 2015.

Raymond, J. (2008). Benchmarking in public procurement. Benchmarking: An International Journal, 15(6), 782-793.

Rotchanakitumnuai, S. (2013). The governance evidence of e-government procurement. Transforming Government: People, Process and Policy, 7(3), 309-321. 
East African Journal of Business and Economics, Volume 3, Issue 1, 2021

Article DOI: https://doi.org/10.37284/eajbe.3.1.298

Thomson, J., \& Jackson, T. (2007). Sustainable procurement in practice: lessons from local government. Journal of Environmental Planning and Management, 50(3), 421-444.

World Bank. (2011). Bank Financed Procurement Manual. Washington, DC: World Bank Publications.

Yamane, T. (1967). Elementary sampling theory. FAO 